\title{
Fiscal Responsibility Laws for Subnational Discipline: The Latin American Experience
}

\author{
by Steven B. Webb \\ World Bank
}

\begin{abstract}
This paper discusses fiscal responsibility laws in Latin America, with special attention to their provisions for fiscal discipline by subnational governments. It discusses why and when such laws might be useful - to help resolve the coordination problem in getting diverse governments to avoid overusing the common national credit market and to help individual governments make a timeconsistent commitment for fiscal prudence. It examines the cases of Brazil, Colombia, Peru, and Argentina, as well as the case of Mexico where other types of laws and regulations aim to achieve the same objectives of solidifying incentives for fiscal discipline at all levels of government. Fiscal responsibility laws are found to be useful in some cases, although the experience is not long enough to be certain, but they are clearly not necessary in every case, nor always sufficient to assure fiscal stability.
\end{abstract}

World Bank Policy Research Working Paper 3309, May 2004

The Policy Research Working Paper Series disseminates the findings of work in progress to encourage the exchange of ideas about development issues. An objective of the series is to get the findings out quickly, even if the presentations are less than fully polished. The papers carry the names of the authors and should be cited accordingly. The findings, interpretations, and conclusions expressed in this paper are entirely those of the authors. They do not necessarily represent the view of the World Bank, its Executive Directors, or the countries they represent. Policy Research Working Papers are available online at http:/lecon.worldbank.org.

The paper evolved from an earlier one of which William McCarten and Mariano Tommasi were coauthors, and their contribution is gratefully recognized without any responsibility for errors that remain here. It was inspired and supported in part by a Subnational Thematic Group research project on Subnational Fiscal Adjustment. Comments and suggestions from Christian Gonzalez, George Kopits, Jonathan Rodden, David Rosenblatt, Mark Sundberg, and David Vetter are also acknowledged with gratitude. 


\section{Laws of Fiscal Responsibility for Subnational Discipline: The Latin American Experience}

Since the 1990s many governments have intensified the search for mechanisms to escape from fiscal populism as a strategy for winning elections and retaining public office. As subnational governments in developing countries have gained fiscal autonomy - spending responsibilities, tax bases, revenue transfers from the center, and the capacity to incur debt- their fiscal behavior has also caused concern. When subnational governments follow unsustainable fiscal policy, it can jeopardize the services they manage (but for which the central government may have ultimate political responsibility), the safety of the financial system, and the country's international creditworthiness and overall macroeconomic stability. Too often the central government then gets dragged in to provide bailouts, which can disrupt its own fiscal sustainability and reward the populist fiscal tactics of the recipient subnational governments.

National governments have tried various ways to avert these problems. One way has been to pass a fiscal responsibility law (FRL) that prescribes proper fiscal behavior for subnational governments (SNGs) and sets incentives - rewards for success or sanctions for failure in following the rules. Argentina, Brazil, Colombia, India, New Zealand, Peru, Russia and South Africa have done so, and Nigeria is considering a proposal for a such laws. Some subnational governments, as in Argentina, Canada, India and the United States, have imposed legal constraints on their own fiscal behavior, to reduce the temptation of state administrations to leave fiscal messes and to improve their creditworthiness in the markets.

This paper aims to shed light on the circumstances and character of FRLs that make a positive contribution to better SNG fiscal behavior, and to understand when these laws either add little or might actually distract and detract from other efforts to obtain prudent subnational fiscal behavior. It considers the context of other laws and rules, and investigates alternate arrangements aimed at obtaining good SNG (and national government) fiscal behavior.

The first section considers why some institution like the FRL could be of use and from there refines the definition of the institution under consideration. The second section enumerates and categorizes the institutions, including but not limited to FRLs, that have served to discourage unsustainable subnational deficits. The third section reviews the institutions that five Latin American countries-Brazil, Colombia, Peru, Argentina, and Mexico - have used to deal with subnational deficits and evaluates the extent to which the institutions have succeeded. The final section draws conclusions about how the characteristics and circumstances of FRLs affect whether they are needed and whether they succeed in promoting subnational fiscal discipline.

\section{What purpose could FRLs serve?}

Governments appear to be interested in FRLs for two related reasons: for an individual government to control its impulses to run excessive deficits and for a group of governments in the same country to make and enforce a mutual agreement that each of them would avoid running excessive deficits. In both situations the FRL would function as a commitment device - in the first case across time to commit future governments and in the second context across space to coordinate governments in various locales.

Motivating fiscal sustainability. In a normative theory of good government, people want to avoid the effects of fiscal crisis - inflationary finance, sudden increase of taxes, disruption of service, and increased borrowing costs - so their governments would equally want to avoid the crises. 
Governments may fail to follow sustainable fiscal policies for a variety of reasons, however (see Alesina 1994 for a survey), and they have adopted various institutions to try to restrain themselves, including balanced-budget rules, autonomous central banks, and congressional oversight committees. Since the late 1990s, governments have added FRLs to the potential and actual arsenal.

Dealing with Free Riders. Suppose that multiple governments share the same currency, central bank, domestic credit market, and (at least to some extent) international credit reputation. Then they will share a common interest in sustainable fiscal balances for the country in the aggregate, to maintain stable prices, a healthy financial system, and good access to international credit.

Individual governments' interests would diverge from the common interest, however, in that electoral pressures, etc., would motivate them to follow unsustainable, or at least risky, fiscal behavior. The individual government would bear only part of the cost of this, but would still receive all of whatever benefit accrued. They could benefit from this, however, only if (most of) the other governments continued to follow good fiscal behavior. So, there might be a prisoners' dilemma, or a situation where the equilibrium of isolated individual choices leads to suboptimal outcomes for all. All the governments would, therefore, benefit from having a system of rules to discourage such defection and free-riding. Inman 2003 develops the prisoners' dilemma model formally for this situation and shows how restrictive are the conditions under which the central government can take a hands-off, nobailout approach under which the market successfully establishes SN fiscal discipline. No Latin American or other developing countries have these conditions (Rodden and Eskeland 2003).

In a federal country, one of the multiple governments - the federal government - already exists for the purpose (among others) of protecting the common interests, has much greater fiscal weight than the others, and typically has special powers, like running the central bank and regulating the financial sector. The federal government also provides transfers to the subnational governments, which often are the main source of SN revenue and give the federal government additional leverage over them. But this may not be enough. Rules of revenue sharing and other rules of the federal system (like the constitution) may restrain the federal government's power over the SNGs. Political considerations may bias the decisions of the federal government away from the optimal; these could be the national political cycle or subnational ones (Braun and Tommasi 2004). For instance when a state government of the same political party as the national government faces a close election, the national government might be inclined to condone the state's fiscal misbehavior by offering a debt bailout or rescheduling guarantee. Also, under some configurations of political institutions, the national executive might need to purchase blocks of legislative votes through provincial fiscal favors, in ways that also break the intertemporal Wicksellian connection, by which voters demand fiscal discipline to protect their interest as taxpayers. Thus the agreement to protect the common interest would not only need to restrain the fiscal behavior of the individual subnational governments but also restrain the behavior of the federal government.

Sub-national debt markets in both developed and developing countries have three important agency problems. First, sub-national borrowers as agents have an incentive not to repay their lenders as principals because they perceive that they will be bailed-out by the central government in case of default, resulting in moral hazard. Second, sub-national borrowers as agents have an incentive not to reveal certain characteristics about themselves to lenders as principals, resulting in adverse selection. Third, banks are implicit agents of the nation, entrusted to maintain the nation's payment system and creditworthiness, and they often abuse this trust by lending to uncreditworthy SNGs (in collusion with the SNGs) with the expectation of a national government bailout in case of trouble. The incidence of these agency problems varies considerably depending on the structure of the sub-national debt market in each country. For instance, the credibility and prudence of a no-bailout commitment by the national government in the event of subnational default depends partly on whether the creditors to the defaulting subnational government are foreign or domestic. 
Legislation with the label fiscal responsibility law does a wide variety of things, but the preceding discussion suggests several features of interest in this paper:

1. Institutions to restrain $\mathrm{SN}$ deficits by preventing them in advance and/or by imposing extra penalties that have effect more quickly and in addition to the normal consequences of fiscal imprudence.

a. Institutions imposed by the national government on the SNGs

b. Institutions imposed by the SNGs on themselves in response to their fiscal environment, including most importantly the rules and behavior of the national government.

2. Institutions to restrain the federal government from

a. Running unsustainable deficits

b. Mitigating the consequences of subnational fiscal excesses.

\section{Channels for strengthening subnational fiscal discipline}

To understand the role of FRLs in enforcing fiscal discipline, one must know the range of institutional tools available for this purpose and, within each country of inquiry, must know what other institutions for fiscal discipline exist, including the overall incentive structure and enforcement capabilities for subnational and national governments and their creditors.

Incentives for prudence in the political system. The political characteristics of the countries affect both the need for subnational fiscal-control institutions and their effectiveness. Indeed, to some extent the political factors that increase the need for an FRL also make it more difficult to pass one and to enforce it successfully. The case studies give attention to several political dimensions: 1) a majority party of the executive in legislature versus coalition (parliamentary) or divided government (presidential); 2) strong party identities and unity, including closed-list nominations for legislature, versus weak parties and open lists; 3) autonomy of subnational governments constitutionally versus national government power to intervene and otherwise control; and 4) strong role for the national legislature and strong influence of governors over legislators, versus strong national executive authority. To the extent that the constitution and party system lead to a centralization of power, the country will have less need for special institutions to coordinate fiscal discipline across governments over time and between states.

Deficit and debt controls external to the budgeting process. Deficits and debt arise from the joint decision of governments and their creditors (including suppliers allowing extended payments), and those decisions are made in light not only of the rules governing issuance of the debt, but also the ex ante expectations about what will happen to the debtor and the creditors if payment difficulties arise - who will lose money or who will be forced into painful adjustment. The decisions of that lending moment - the original sin — become a fait accompli conditioning the subsequent decisions. This points to two important dimensions of control of government borrowing: 1) their type or timing - ex ante controls or ex post incentives - and, 2) whether they act on borrowers or lenders. Together these make a matrix with four cells, as in Table 1 below.

Ideally, any lending should be subject to constraints in all four quadrants. Relying only on ex ante constraints, without ex post consequences, gives irresponsible borrowers and lenders a big incentive to get around the initial hurdles and do transactions that will latter get bailed out. (This happened in Brazil in the early 1990s.) Relying only on ex post consequences allow irresponsible (and large) entities to build up such large debts that the national government or the rest of the world will not have the nerve to enforce the consequences. Ex ante constraints are critically important in 
economies where banks and financial institutions are owned by governments and financial markets are not fully liberalized. Under such conditions credit allocation decisions are not strongly driven by considerations of protecting lenders interests. Relying only on constraints on borrowers means that lenders will still push loans and may find politicians with recklessly high discount rates, willing to borrow despite the rules.

Table 1: Channels for control of deficits and debt

\begin{tabular}{|c|c|c|}
\hline & For borrowers & For lenders \\
\hline $\begin{array}{l}\text { Ex-ante } \\
\text { controls }\end{array}$ & $\begin{array}{l}\text { All governments: } \\
\text { - debt ceilings } \\
\text { - deficit targets } \\
\text { - restrictions on international borrowing } \\
\text { SNGs only: } \\
\text { - regulation of SNGs' borrowing, based on } \\
\text { fiscal-capacity criteria (regulations by central } \\
\text { government, central bank, or other institution) }\end{array}$ & $\begin{array}{l}\text { All governments: } \\
\text { - no direct central bank financing } \\
\text { - restrictions on international borrowing } \\
\text { - regulations by central bank or other } \\
\text { financial supervision agency } \\
\text { SNGs only: } \\
\text { - credit rationing to states } \\
\text { - increased capital requirements for } \\
\text { lending to risky SNGs }\end{array}$ \\
\hline $\begin{array}{l}\text { Ex-post } \\
\text { consequences } \\
\text { (as incentives } \\
\text { for ex ante } \\
\text { caution) }\end{array}$ & $\begin{array}{l}\text { All governments: } \\
\text { - limits on central bank financing } \\
\text { - no bailouts (from central government or } \\
\text { from international community) and no debt } \\
\text { workout without adequate conditionality } \\
\text { - publication of detailed fiscal results } \\
\text { SNGs only: } \\
\text { - central government does not accept SNG } \\
\text { debt } \\
\text { - debt service withheld from transfers to SNGs }\end{array}$ & $\begin{array}{l}\text { All governments: } \\
\text { - strong supervision of banks } \\
\text { SNGs only: } \\
\text { - regulations require capital write-offs } \\
\text { for losses from SNG debt }\end{array}$ \\
\hline
\end{tabular}

For the constraint on borrowers, one can also distinguish between institutions - constitutions, FRLs, other laws, or well-established regulations - that encourage fiscal restraint. First, some of them set specific fiscal targets, whereas others emphasize procedures for setting targets and monitoring their implementation. Second, the specific targets could be for the bottom lines of fiscal performance - such as debt stocks and overall balances - or for features of the budget that contribute to flexibility to adjust to shocks - such as the current balance or the share of spending going to investment or non-labor expenses.

Third, among FRLs, some are national laws that apply to all levels of government, or at least to the national and intermediate (state, provincial) levels. The FRLs in Brazil, Peru, and Colombia are this type. From the SN point of view, these are top-down systems. ${ }^{1}$ In other countries, like India and Argentina, the national government passes an FRL only for itself, and hopefully (but not imperatively) this sets the framework, incentive, and example for the SNGs to pass their own FRLs voluntarily. These bottom-up systems are analogous to the successful federations that maintain fiscal discipline in through incentives, like the United States, Canada, and lately Mexico. They require more time to establish the credibility of the federal policies that set the incentives, and thus more time to judge if they are working.

\footnotetext{
${ }^{1}$ Ter-Minassian and Craig 1997 argue that such top-down control is necessary for SN fiscal discipline in developing countries. Rodden and Eskeland 2003, with more evidence to consider, see prospects for combining hierarchical control with market discipline, and gradually letting the latter take more weight.
} 


\section{Country institutions and experiences}

To help understand the role or potential role of a fiscal responsibility law, this section describes the institutional arrangements, history and political context of efforts to instill fiscal prudence at multiple level of government in the countries of our sample-Brazil, Colombia, Peru, Argentina, and Mexico.

Brazil has one FRL for all levels of government; it uses both ex ante rules and legal penalties to contribute to the consolidation of a critical mass of consensus for fiscal prudence among powerful governors, with few party loyalties but strong influence over national legislators. executive. Colombia, a unitary country of "autonomous" departments, already had various laws constraining subnational borrowing, and to get more institutional backing for fiscal balance at the national level they passed an explicit FRL in 2003. It adds to the ex ante constraints on SNGs, although without strong enforcement provisions like Brazil, and sets up some transparency and accountability procedures for encouraging fiscal prudence at the national level. Peru has had a national-level FRL since 2000, and then in 2002-03 a wide range of subnational government obtained substantial fiscal autonomy, including the right to borrow. Therefore, the government revised the FRL in 2003, with provisions for the SNGs as well as tighter constraints on national fiscal behavior. In Argentina, a collection of individual FRLs for the national government and for many but not all provinces initially showed promise but then failed, due to intra-party conflict, to non-participation by key provinces, and to other contradictory commitments that the FRLs failed to overcome. The FRLs emphasized ex ante rules, but without strong enforcement and without universal application. Finally, Mexico is a case of fiscal prudence without a FRL even under consideration. The states have too much constitutional independence for the federal government to impose a top-down FRL, and so it is using financialsector regulations to motivate state-level prudence and has issued public decrees of new federal-level fiscal procedures, whose implementation a politically autonomous congress can monitor.

\section{Brazil}

Political and fiscal constitution. Federalism in Brazil revived with the return to democracy, giving legitimacy to subnational governments before the federal level. From 1982 to 1989 there was a sequence of electing governors, then electing mayors, electing a new congress with constitutionmaking authority, completing the new constitution, and finally holding the first direct election of the president. Thanks to the strong representation of SNGs in the 1986 congress, the 1988 constitution gave them a lot of authority and resources.

The vertical imbalance of intergovernmental relations in the constitution was matched with important horizontal imbalances between the states, in per capita congressional representation and fiscal transfers. The non-cooperative outcomes in representation and revenue sharing set the stage for non-cooperation in fiscal prudence to protect macroeconomic stability, especially because mainly the large rich states had access to credit markets and thus the opportunity for serious fiscal imprudence.

Debt history. From the restoration of subnational democracy through 1998, Brazil had three major subnational debt crises. The agreements to resolve the crises tried to limit future SN deficits and the availability of financing for them, but they also had four characteristics that in fact made the next crisis more likely. First, they reinforced the perception that the federal government was prepared to provide debt relief to any state requiring it. Second, they provided such relief in the form of

rescheduling, rather than forgiveness, so that the stock of debt kept growing rapidly, with most of the repayment burdens falling on the successors to the governors who defaulted and rescheduled. Third, limits on debt service largely eliminated the expected future cost of current borrowing and interest 
capitalization for states already heavily indebted. Fourth, the debt relief bought out (without penalty) the foreign and private creditors to the SNGs and left the federal government holding the debt. Thus the SNGs suffered minimal consequences for their imprudence and their creditors suffered almost none, and so until 1998 the ex ante constraints written in the rescheduling agreements were usually quickly and even enthusiastically evaded (Dillinger 1997; Rodden 2003).

Although the large Brazilian states all ran excessive deficits, a few smaller states had good fiscal performance, which helped them attract private investment. Thus the individual states chose between extremes of good or bad fiscal behavior. The intermediate course of struggling through without substantial bailouts but also without strong enough performance to attract the attention of investors was not as attractive as the two extremes. With neither a coordinating mechanism nor a critical mass of fiscally prudent states, which might have blocked bailouts in the early 1990s, the adverse incentive environment caused some states to switch from good to bad fiscal behavior.

Prelude to the FRL. In 1999-2000 the vicious cycle of failure in discipline and cooperation came to a halt, as the deeper political and economic incentives had changed. Fernando Henrique Cardoso brought down federal deficits and inflation in 1994 when he was Finance Minister and then was elected president twice on the popularity of that achievement, even with its imperfections. That was an important seed-crystal to catalyze political support for fiscal prudence. Cardoso made political alliances with the governors of three of the four largest debtor states, including the most important, São Paolo. That would form the core of a critical mass of states ready to cooperate in fiscal restraint, making it worthwhile for additional states join at the margin of cooperation. To an individual state the value of non-cooperation (excessive borrowing) may have declined as well, from the effects of debt overhang and defaults driving creditors away from the market, and from the active interventions of the federal government, of which there were four in addition to the FRL.

Two measures focused on the SN borrowers and two on their creditors. For the borrowers there were the new Senate Resolution (SR 78) on limits for state borrowing and the framework law for individual renegotiations of SN debt. The constitution gives the Brazilian Senate unusually broad authority in state fiscal matters, with the power to approve or reject state borrowing requests, plus various controls over the central bank. In 1999-2000 the Senate reversed its previous trend of opening borrowing opportunities and, instead, set binding constraints on state borrowing and forbade some types of borrowing altogether.

Law 9696 law of 1997 for the renegotiations of state debt over the next two years set conditions that included targets for declines in debt and deficits ratios, ceilings for personnel spending and investment, growth in own revenues, and privatization of state enterprises. The law also stipulated ex post consequences more strictly than in previous debt negotiations - no federal guarantees for state debt, interest rate penalties on existing state debt held by the federal government, increases in the debt service ceilings, and deductions of all debt service directly out of the revenuesharing participations from the federal government. Although both these measures resembled previous ones, they set tighter limits and gave the government a stronger mandate to withhold transfers from states that failed to meet their agreements (Dillinger 2002, Rodden 2003).

On the lending side, the National Monetary Council (CMN) ordered the Central Bank, as supervising authority for all domestic banks, to limit each bank's total lending to the public sector and to prohibit bank lending to any state that is in violation of the debt and deficit ceilings of the Senate Resolutions or in default the federal government or to any other bank. The CMN resolutions specified penalties for any bank that violated the rules. Also, the privatizations required in the rescheduling agreements included the state owned banks, eliminating them as a source of debt 
financing. Singly, these measures would probably not have succeeded, and even as a group they might have failed to stem the momentum and precedents of state deficits and debt rollover.

FRL. Consequently Brazil also passed an FRL in May 2000, adding to the mix of policies that created a critical mass of states supporting cooperation (Alfonso 2002; Dillinger 2002). ${ }^{2}$ The FRL is a unitary law, covering the federal and state levels. It sets minimum standards for state budgeting, personnel management, and debt management. The annual budget of each SNG has to be consistent with its multiyear budget plan and with the federal fiscal and monetary program. It systematizes and reinforces the restrictions on personnel spending, deficits and debt that were in the debt rescheduling agreements and other earlier measures. It also contains specific provisions for authorities in their final year in office. Some of its provisions were in the Law 9496 and the Senate resolutions. Although the bulk of the law pertains to ex ante conditions, it does reiterate the requirement that the federal government deduct from tax-sharing participation transfers any money owed by an SNG to the federal government and agencies. Debt and labor contracts in violation of the FRL are not legally valid, which would be negative ex post consequence for any lender who thus would thus lose its money.

Building from mandates established in SR 78, the FRL requires SNGs seeking loans first to apply through the Ministry of Finance and prove that they are in compliance with the new law. Furthermore any borrowing that has taken place above the threshold ceilings established by the senate is required to be repaid in full, not including interest, which is a penalty to lenders as well as borrowers. In the interim, governments are ineligible for discretionary fiscal transfers or federal guarantees and are prohibited form contracting new debt. The new law also prohibits governors and mayors from contracting obligations to pay within the last six months of their administrations, unless these can be paid off in the remainder of their term in office. And finally, it authorizes and even requires the federal government to garnish intergovernmental transfers to service loans.

A companion law to the FRL specifies criminal penalties — fines and even jail—for officials who violate the rules. Critics point out the clumsiness and slowness of the Brazilian judicial system makes any convictions unlikely and thus unthreatening, but the experience so far suggests that officials also fear getting entangled in that legal morass. SNG executives seem to be using the FRL and its companion as an excuse to say no to demands for special interest expenditures and transfers that would violate the FRL. Some state governments have put up posters telling the penalties, as a reminder of why they are turning down special requests.

The fiscal performance of Brazil's SNGs has improved markedly over the last few years. The average ratio of debt to net revenue declined from 3.8 in 1998 to 1.9 in 2001 (Alfonso 2002). At the end of 2000, 10 states still had deficit ratios above the FRL target; by the end of 2001 only six were out of compliance. They adjusted personnel expenditure, including public pensions, even faster; of the 18 states that were out of compliance with FRL targets in 2000, 13 managed to comply by the end of 2001. (BNDES, 10 May 2002) Adjustment by SNGs continued in 2002 and 2003. How much of this is due to the FRL? Some but not all. One cannot specify a fraction, because the states as a group seem to have jumped from a bad equilibrium to a relatively good one. The FRL contributed to that switch. The switch started before the FRL, but it contributed to sustaining the switch. It is still possible that the shock of national level macroeconomic instability could knock the system back to an

\footnotetext{
${ }^{2}$ A lack of horizontal accountability between the legislatures and the president, coupled with the president's inability to really on a supportive coalition in the congress, fueled expectations that the FRL's measures could be easily amended - or even aborted - in the future; this in turn made it possible to muster the legislative votes needed for its passage, notwithstanding high levels of political party fragmentation.
} 
uncooperative outcome, but the FRL seems to be contributing to the probability that the cooperation in SN fiscal prudence will continue.

\section{Colombia}

Intergovernmental relations. Colombia's formal government has traditionally been centralist, to offset the natural geographic fragmentation and to try to contain the centrifugal forces of strong special interest groups. Overlying the natural geographic fragmentation, strong non-regional interests dominate the political dialogue - some operate within the legitimate political system, like teachers and producers of coffee, cattle and sugar, while others are outside and challenging it, namely two guerilla movements, the paramilitaries, and drug producers. The interests within the system enjoy unusual leverage to make demands on the government both because of the implicit threat to ally with illegitimate forces and because of institutional features they have learned to exploit.

Decentralization started in Colombia with the 1968 deconcentration of national revenues to subnational administrative units, with revenue sharing set by formula and mostly earmarked for specific sectors (Bird 1984). The 1991 constitution (which also made the office of governor an elected post) and Law 60 of 1993 expanded the amount of revenues assigned to departments by broadening the base of the existing revenue-sharing system (the situado fiscal). The Constitution and Law 60 committed the national government each year to expand revenue sharing with territorial governments and entities until it would reach nearly half of all current revenues by 2002 .

Cofinancing funds, transfers to municipalities for capital investment needs, remain important loopholes in the hard budget constraint for states.

Subnational Debt. In the late 1980s and 1990s the trend toward political decentralization was accompanied by more freedom for subnational domestic borrowing. There was no effective ex ante control of cash advances from banks, and subnational debt with the banking sector rose from $2.6 \%$ of GDP in 1991 to $4.6 \%$ in 1997 . $^{3}$ To increase the central government's control over subnational debt, the so-called Traffic Light Law of 1997 introduced a rating system for territorial governments, based on the ratios of interest to operational savings and of debt to current revenues. Highly indebted local governments (red light) were prohibited from borrowing, and intermediate cases (yellow light) were required to obtain permission from the Ministry of Finance. The law was not fully effective, however, as some governments with a red light rating obtained new financing without permission of the Ministry of Finance. "Out of 21 departments that required permission for new loans in 1997, 10 received new credit without permission from the Ministry [...] In order to be able to violate the law, departments presented defective financial information, and the financial institutions made superficial analysis of it. In addition, the Ministry of Finance gave its authorization in cases where it should have denied it." (Echevarria et al, 2000, p.9). Rather than moving from yellow to green, as expected, the departments often changed from yellow to red.

The importance of bank lending as a source of financing for subnational governments in Colombia makes bank regulation an alternative way to control subnational borrowing. The Superintendency of Banks altered its requirements regarding provisions against non-performing territorial loans. After SNG borrowing from banks expanded in 1993-1994, the Superintendency required any subnational loan with over a year maturity to be classified as risky and to have some provisioning. These regulations were relaxed again in 1996, leading to two years of high borrowing. In 1999, the traffic-light law was strengthened to require banks to provision fully for the debt of any territory with a red rating, thus increasing the cost of those loans for banks.

\footnotetext{
${ }^{3}$ For further details, see Dillinger, Perry and Webb (2001).
} 
$F R L$. In a new attempt to implement fiscal rules to stabilize subnational finances, Colombia passed Law 617 in 2000, which functioned in many ways as a Subnational FRL. It is also still too early to tell whether the law brings about a structural change in fiscal outcomes, but the provisions appear to move in the right direction: ${ }^{4}$

- Primary current expenditure may not exceed non earmarked current revenues, and should not exceed a fixed percentage, depending on the state or municipality category; governments must make across the board cuts whenever effective non-earmarked current revenues are lower than budgeted.

- Expenditure for state legislatures is limited.

- State and municipal central administrations are not allowed to make transfers to their public entities.

- Strict limits apply to creation of new municipalities, and municipalities proven non-viable have to merge.

- When subnational governments do not comply with the limits imposed by the Law, they have to adopt a fiscal-rescue program to regain viability within the next two years.

- To promote transparency, there is an extensive list of characteristics and requirements for the election of governors, majors, legislators and their relatives.

In June 2003 the government passed a Fiscal Responsibility Law, labeled as such and applying to the national as well as the subnational governments. It specifies a process for setting budget targets and linking them to target ranges for debts and deficits. Regulations for the law build on the current practice of publishing quarterly fiscal results, defining deficits on the basis of cash revenue and accrual of spending obligations, and defining debt to include floating debt. The FRL sets a target to eliminate reservas presupuestales in two years. The other part of floating debt, cuentas por pagar, will be counted as regular debt and will thus be controlled by the fiscal/financial plan. To help with fiscal discipline at all levels, the FRL will prohibit the national government from lending to an SNG or guaranteeing its debt if it is in violation of Ley 617 of 2000 or Ley 357of 1997, or if it is in arrears on any debt service to the national government, Indeed, a subnational government with those fiscal violations may not legally borrow from anyone.

To discourage electoral cycles in fiscal policy, the FRL also prohibits any government from committing future spending (vigencias futuras) or increasing personnel spending in an election year. For the subnational governments there are additional restraints on deficits: eliminating the intermediate category in Ley 357 (thus putting tight fiscal restraints immediately on SNGs that show signs of problems), and requiring that departments and large municipalities get satisfactory credit ratings from international rating agencies before they borrow. While some of these legal measures need further refinement, such as through their regulations, they represent important advances as long as they are enforced well.

The strategy for fiscal control in the proposed FRL differs between the national and subnational levels, because of the different constitutional constraints they face on fiscal policy. For the subnational governments the Constitution specifies most of their revenue, via transfers, and gives them little leeway to raise more own revenue, so the proposed FRL strengthens the ex ante restraints on subnational deficits to complement the existing restraints on subnational spending, mostly in Ley 617. For the national government, where most of the fiscal problems have centered, the FRL increases transparency but still does not give the Ministry of Finance a hard budget constraint with which to enforce fiscal discipline in the face of special-interest demands, including those coming through SNGs on behalf of teachers and others. The Constitution, debt obligations, pensions, and other legal entitlements specify almost all outlays for the national government, so the FRL focuses on

\footnotetext{
${ }^{4}$ For further details see Oliva (2001).
} 
limiting the deficits so that the adjustment will have to concentrate on the tax side and thus eventually motivate political restraint on spending. Control over spending would improve only if less spending is legally pre-committed to special interests and if the new budget law (drafted in 2003, to be discussed and ) gave the Ministry of Finance the authority in case of a revenue shortfall to curtail spending in order to meet the fiscal balance in the approved budget. The draft did not make this provision, however, and the FRL alone cannot control the national deficits.

\section{Peru}

Intergovernmental relations. Peru is a unitary state, with even more of a centrist tradition than Colombia, since Lima has always been the economic and political center. Decentralization came to the fore as part of a democratic reaction after Fujimori's exit. The 2002 decentralization law foresees having half or more of public sector spending managed and to some extent even allocated by subnational governments - districts, municipalities, regiones, and perhaps even macro-regiones. This will be a major change from the previous situation where less than 10 percent of public spending was managed by local governments, namely the local municipalities and districts. Peru's transfer system is still evolving: after the devolution of specific investment projects to the SNGs, one expects the creation of some non-earmarked transfers to the regions and further devolution of responsibilities. The playing field is not only uneven, but lacks clear boundaries and rules of the game.

$S N$ debt. In contrast to the experiences of some other Latin American countries, like Argentina, Brazil and Colombia, the behavior of subnational public finances in Peru has not affected the country's financial sector or macroeconomic stability. The government intends to keep it that way, but it will now take more concerted effort, because changes in the constitution and new laws since 2002 have given the subnational governments the authority to contract debt, internal and foreign. For those governments to operate effectively, they must avoid over-indebtedness, even at levels that might not pose a financial danger to the nation. Prior to the recent decentralization, some municipalities had amassed considerable debt relative to their fiscal size. The majority of the debt was short-term payment obligations, owed by the largest cities. Their formal debt was mostly to the Banco de la Nación, which has a good record of repayments, since they have automatic access to transfers, from which debt service can be deducted. They have also tightened their lending procedures in recent years.

FRL. Before it started decentralization, Peru passed a law of Fiscal Prudence and Transparency (LFPT) in December 1999, effective 2000. It required that the annual fiscal deficit of the non-financial public sector would not exceed the limit in the Marco Macroeconomico Multianual and not exceed 1 percent of GDP, except in congressionally authorized cases of national emergency or international crisis, when the deficit could go to 2 percent. Although the initial law improved transparency and helped reduce national-level deficits, it had two main problems: first, it did not keep national government deficits within the legal limits, and second it did not make provisions for the subnational governments. In April 2003 the government passed a new law, making several amendments intended to rectify these problems. Their success will depend on enforcement, the first steps for which was the issuance of regulations.

The new law makes four key improvements for fiscal prudence at the national level ${ }^{5}$ :

\footnotetext{
${ }^{5}$ In two areas, the requirements in the new law were relaxed a little in order to fit with administrative and economic realities: Public spending is allowed to grow as much as 3 percent per year in real terms, instead for just 2 percent. Since the economy has grown at up to the 5 percent in recent years, allowing public spending to grow at 3 percent will not prove harmful as long as it does not out-pace revenues (which the deficit limits
} 
- A new clause prohibits any administrative or legal norm that interferes with the correct execution of the Marco Macroeconómico Mulitianual (MMM), called for in the original law, especially with respect to the fiscal deficit targets.

- In election years, the government may only spend up to $60 \%$ of the annual spending allocation in the first 7 months and may only use $40 \%$ of the annual limit on the deficit in the first semester.

- Quarterly monitoring of the fiscal performance is required and, in case of revenue shortfall, adequate remedies to revenues and/or expenditures must start in the next quarter.

- If the fiscal deficit limits are relaxed, as under circumstances allowed in the law, then the transition to return to the regular rules is better specified.

The previous law did not consider the subnational governments (SNGs, regional and local), which now have more fiscal resources and autonomy and are explicitly allowed to borrow internationally and domestically. The new law makes five key provisions for the SNGs:

- Each regional government must prepare and publish an annual development plan that is consistent with the national MMM (including the size of fiscal deficit).

- All SNGs have to keep a non-negative primary balance on average in the last 3 years in office.

- The overall public-sector deficit limit in the law applies to the subnational as well as national levels - an important ex ante constraint. Regulation needs to define the procedure for translating the aggregate fiscal limit into an allocation of borrowing limits for each of the governments, national and subnational.

- The FRL sets some ex ante constraints for subnational borrowing; SNGs can only borrow internationally with the guarantee of the national government. The guarantee for any loan requires compliance with the Annual Debt Law and demonstration of the capacity to pay, which provisions give the national government the authority to veto SN borrowing. ${ }^{6}$

- If an SNG violates the targets in the law, the national government must withhold some transfers to make the required payments of debt — an important ex post consequence, if well enforced.

Peru is decentralizing quickly, as have other countries, but it is unique in the passage of an FRL so early in the process, even before the subnational governments are fully defined or established. It is still too soon to know the results, but if the FRL is well enforced, it will help establish a culture of fiscal prudence in these new governments.

\section{Argentina $^{7}$}

Political and fiscal constitution. Argentina has a federal presidential system with generally stronger presidents than in Brazil, although governors still have a lot of power. Since the 1930s when the federal government abolished most existing provincial taxes and introduced national income and sales taxes, an increasingly complex system of revenue sharing (coparticipation) has been the

should assure, since they are specified as a share of GDP). Second, in the exceptional cases, the deficit can go as high as 2.5 percent of GDP, instead of only 2 percent.

${ }^{6}$ SNGs are not prohibited from getting domestic credit without the guarantee, but this should theoretically come within the overall public sector deficit constraint. Thus, the national government could use the requirements for getting credit with the guarantee and other means to force SNGs to report their non- guaranteed borrowing and to keep it within the global deficit constraint.

${ }^{7}$ The discussion here of Argentina covers the late 1980s and the 1990s, from the restoration of democracy until the economic crisis of 2001-02. 
backbone of provincial revenues. In the 1990s coparticipation accounted for two-thirds of total provincial revenues, with wide variation between provinces - about half in the largest four provinces, but over 90 percent in the smallest and poorest. The distribution of funds among provinces is determined largely by coefficients fixed in the 1988 coparticipation law. Nevertheless, the federal government has some leverage over the provinces because transfers can be created or altered through legislation; new transfers can be offered as a quid pro quo for provincial compliance with federal initiatives.

Subnational debt. In the 1980s, provinces borrowed a lot, much of it from their own provincial banks, which then discounted the loans to the central bank, effectively giving provinces no hard budget constraint, but rather a share in the seigniorage tax and contributing to hyperinflation. The subsequent stabilization centered on the Convertibility Plan, introduced in April 1991, fixing the Argentine exchange rate to the U.S. dollar and requiring that the monetary base not exceed the dollar value of international reserves. This eliminated the central bank's role as lender of last resort and hardened the financial budget constraint on the federal and provincial governments.

Through the 1990s the Menem government mainly followed a market-based strategy of coordinating fiscal discipline between levels of government: the central government would enforce hard budget constraints ex post and force the provinces to pay their debts. This was to provide incentives for voluntary ex ante prudence about borrowing at the subnational levels. During the 1990s the strategy seemed to work, although a longer track record was needed to establish it firmly. The successes of the Menem-Cavallo team in getting the provinces to go along with the national adjustment program resulted from a conjuncture of historical opportunities. Provinces followed a pattern of more fiscal restraint where the provincial government was of the same party as the national president. Indeed, this pattern seems to go back to the 1980s (Jones, Sanguinetti, and Tommasi 1997). Buenos Aires and Santa Fe were the most important cases of Justicialista provinces adjusting promptly after the start of the national stabilization. Getting those two to adjust before the 1995 crisis provided a critical mass of fiscally sound provinces and allowed the central government to take a hard line in forcing other provinces to adjust.

Some provinces, not most of the biggest, over borrowed in the early 1990s, then had to suffer consequences in the 1995 economic downturn (only slightly softened by federal intervention), after which they should have learned a lesson in the virtue of fiscal prudence. But the quick resumption of growth took away most of the pain; provinces resumed borrowing, especially Buenos Aires. By the end of the 1990s, the absence of the ex ante fiscal controls had allowed a number of provinces to over borrow, and according to the strategy of Menem-Cavallo (by then departed) some of them would have suffered painful consequences. By the late 1990s, however, the political context was changing, with serious rifts in the Justicialistas. The new government of de la Rua, taking office in late 1999, was not prepared with ideology or political party cohesion to take a strong line in enforcing fiscal consequences on the provinces.

FRLs. At the national level, faced with a deteriorating budget balance and growing debt payments, the Argentine Congress approved a Fiscal Solvency Law in September 1999. Besides establishing numeric limits for the central government's fiscal deficit, it limited the growth of expenditures, stipulated the adoption of pluri-annual budgeting, created a Countercyclical Fiscal Fund, and implemented transparency measures regarding public finances - the features favored by the recent literature on fiscal rules. The Law required reaching fiscal balance no later than 2003 and set nominal ceilings for the national-level non-financial public sector deficit between 1999 and 2002. But they were broken in every year. 
Although the national law did not include conditions for subnational governments, it invited the provinces to pass similar laws of their own, and several did. The provisions of the laws differ across provinces, as did the degree to which they were adhered to, even before the economic crisis in 2001. All the provincial FRLs have limits on the deficit or overall debt, and most have both (Braun and Tomassi 2003). More importantly, however, the city of Buenos Aires and three of the four large provinces did not pass any FRL. They contain well over half of the nation's economy, and their nonparticipation undercut any hope for the system of FRLs to assure that no government would spoil the common good of fiscal prudence. The tradition of not respecting rules goes beyond the FRLs. For instance, 16 of 24 provinces have constitutional limits on the ratio between debt service and total revenue - 20 to 25 percent - but in 2000 , only 10 of the 16 provinces complied with those limits; results for 2001 were much worse (Braun and Tomassi 2003).

In 2001 the FRLs stopped working because of the extreme mismatch between the national government's fiscal and monetary policies in the context of a fixed exchange rate. Although the federal government's FRL lacked enforcement power, the more fundamental problem was the government's many legally inflexible spending obligations, most notably debt service and provincial transfers. Federal-provincial agreements in 2000 had set nominal peso (= US dollar) floors on transfers to the provinces that would last several years during a transition to a long-term arrangement of moving-average calculations that were more favorable to the federal government. Unfortunately the recessions of 2001 and thereafter reduced revenues to the point that the federal government could not make the promised transfers and defaulted on those and other obligations, paying them with debt that circulated as money (Gonzalez, Rosenblatt and Webb 2003). Even with stronger enforcement procedures on paper, the FRL could not have solved the problem.

The provincial FRLs also had shortcomings that would have been problematic even if the collapse at the top had not come first. They lacked enforcement power and a critical mass of states had not passed them-Buenos Aires province, Buenos Aires city, and Santa Fe - the same entities that had formed the core group for fiscal adjustment in the early 1990s. The Compromiso Federal of 2000 did not have contingencies to assure fiscal sustainability in down-side scenarios of growth. It arranged to share benefits of growth but not to share the cost of recession. All the governments were benefiting from the public asset of a stable currency and using it to access credit markets, but they failed to appreciate the fragility of the asset and the need to coordinate efforts - ex ante controls - to avoid overusing it. The attachment of co-participaciones at Banco de la Nacion looked so much like a federal guarantee of the provincial debt that most lenders did not fear ex post consequences, and there were no ex ante constraints from their side.

\section{Mexico}

Among the countries discussed here, Mexico has no FRL at the national level. Many states have laws, or traditions, regarding the build-up of deficits or surpluses (rainy-day funds), but none has what we call an FRL. Nonetheless, new institutions of SN fiscal discipline have emerged in Mexico since the late 1990s, which seem to be achieving by other means some objectives of FRLs.

Intergovernmental relations. Although Mexico'sconstitution since the early $20^{\text {th }}$ century has devolved considerable autonomy to the states, and power to the congress, in the 1970s and 1980s the dominance of the PRI party and the power of the president within the party effectively short-circuited that federalism and balance of power between branches of government. For reasons unrelated to SN finances, the hegemony of the PRI ended at the state level in the late 1980s and the 1990s, and at the federal level in the late 1990s, culminating in a change of party in the presidency for the first time in seven decades. Three major parties now contend for office and share power in the national congress 
and many state congresses, which requires the president and many governors to negotiate their budget and other legislation with the opposition.

Subnational debt. In the time of PRI hegemony, subnational debt was guaranteed by the federal government, which also kept informal as well as formal veto power over issuing it. Ex ante controls and ex post consequences existed and usually kept subnational debt at sustainable levels, but the important controls and consequences were outside the formal rules and based on personal political connections. Since the 1990s, however, the old way of dealing with SN debt would no longer work in the new environment, and the federal government started to recognize this and change the regime in the 1990s. The general debt and economic crisis of 1995 also included the states, who then got relief through rescheduling into long-term inflation-indexed debt at affordable but positive real interest rates and through four years of assistance payments (from the president's discretionary fund and in addition to the other, regular transfers). To avoid a recurrence of the fiscal crisis, each state had to agree to a fiscal adjustment program designed in the Secretariat of Finance (SHCP), which monitored compliance prior to disbursement of the annual tranches of assistance, set a precedent of fiscal consequences, and brought most states to a good financial situation by the end of the 1990s. The indexed debt that the banks were force to accept helped them avert total ruin and collapse of the system, but illiquidity of the assets and low return inflicted some penalty on the borrowers as well. The government also ended its policy of formally guaranteeing subnational debt, although as a transition it agreed to accept and execute contractual mandates by which the borrowers pledged their revenue-sharing transfers as collateral for the debt service.

Non-FRL debt control. By 1999, the federal government saw the need for change toward a more traditional hard-budget constraint for SNGs and so brought in a whole new system, starting in 2000. The new borrowing framework has four key elements:

1. Giving commercial and development banks ex ante signals about the riskiness of state debt, by making the debt subject to the same borrower concentration limits as other debt and by requiring that capital-risk weighting reflect riskiness, based on international credit ratings. 2. Giving strong incentives for borrowers to publish their fiscal and financial information. 3. Eliminating discretionary transfers from the federal government, at least those at the discretion of the executive.

4. Ending SHCP's role as fideicomiso for collateralizing debt with participaciones. Lenders and the SN borrowers typically organize their own fideicomisos for this purpose, and the absence of direct federal government involvement aims to reduce the administrative ease and thus the likelihood of any bailouts.

The new Mexican regime seems to be potentially complete, with coverage in all four quadrants of table 1. The first two elements aim both to deter states in advance from excess borrowing and to reward states that follow prudent policy. The credit ratings have become badges of good behavior with positive value in the electoral arena, independently of their effect in improving access to credit and reducing its cost. The third and fourth measures are commitments from the federal level that it will in the future let states and lenders face the market consequences of excess deficits, which should impose ex post costs for abuses. The system is very new, however, and only after it has endured a few tests will one be able to say whether the ex ante controls and the commitments to impose ex post consequences were adequate. Basing the subnational borrowing regime on incentives, not strict requirements, works best in a non-crisis environment, so it would be good to put up some more institutional vetoes to prevent bailouts in a crisis, which would undermine the incentives. Although Mexico does not have a national FRL, state governments have incentives now to make their budgets and balance sheets attractive to voters, credit rating agencies, and lenders - taking the sort of measures that an FRL might demand. Nonetheless, the FRL features for 
transparency and medium-term fiscal management would benefit the federal as well as subnational governments in Mexico.

\section{Conclusions}

While there is much that FRLs might do, the evidence of their effects is meager, as only a few countries have actually tried them, and only recently. Although political consensus for fiscal prudence is clearly a necessary condition to launch a successful FRL, the test of its effective implementation comes when the consensus breaks down, and then one sees whether the institution works to help the remaining stabilization champions restrain the fiscal excesses that the populists might want.

Evidence from the sample here indicates that FRLs are neither necessary nor sufficient for achieving fiscal prudence at multiple levels of government. They can be useful as mechanisms to coordinate and sustain commitments to fiscal prudence, but they are not a substitute for commitment. They should not be viewed as ends in themselves, perhaps to be bought with fiscal favors.

In Brazil, the FRL's contribution seems to be positive, by adding to the collection of other measures to shore up a coalition of states with the federal government in support of fiscal prudence. Still the story there is short, covering mainly the latter part of the Cardoso administration, which brought together a conjunction of stabilization commitment by the president and a political alliance with most of the important states, including the largest. Perhaps the real tests will come in the Lula administration, where the initial results show continued fiscal discipline, and after the end of temporary prohibitions on any new subnational borrowing.

A surge of stabilization commitment also prevailed in Argentina in the mid 1990s, when its prospects for fiscal prudence looked good (Dillinger and Webb 1999). When Argentina came to its version of the FRL at the end of the 1990s and into 2000/01, however, the conditions were much less favorable. Political relations between the federal government and Buenos Aries province (relatively much larger than any Brazilian state) had strongly soured, leading that state and most other large ones to stay out of the FRL coalition. Thus one could say that Argentina never put in place a full FRL system even on paper, and the limited one was too little too late. The experience in Mexico seems to show the possibility for achieving the objectives of an FRL by other means.

Establishing an FRL or other institution to constrain SN debt and deficits works only if the governments in question start from or are brought to a position where they do not have debt overhang. In other words, if the service on existing debt is already too large to pay realistically in the political economic situation, this attenuates greatly the incentive from an FRL to behave with fiscal responsibility. Consequently, a set of $\mathrm{SN}$ fiscal adjustment and debt rescheduling programs often must complement or precede the implementation of an FRL. To work, the programs must strike a balance between being sufficient to eliminate the debt overhang and being so generous as to seem to reward fiscal irresponsibility of the past (or to fiscally hamstring the national government). Mexico achieved this, and perhaps Brazil and Colombia have as well. Argentina did not.

Even when FRLs are effective, they cannot do the job alone. The potential contribution depends on how well it complements the rest of the institutional framework for SN fiscal restraint. In Brazil a number of supportive measures came in advance-making labor and pension laws more flexible, giving subnational governments substantial tax bases, using rules for debt renegotiations to reduce the salary bill as a share of revenue, etc. Similarly, the Colombian national government has passed a number of measures to restrict subnational borrowing and inflexible spending, so the FRL will have that support. At the national level, Colombia is still introducing the budgeting reforms to 
reinforce the new FRL. By contrast, in Argentina, the partial system of FRLs failed when the federal government had boxed itself in with the convertibility law, debt service, and commitments to floors for transfers to provinces, all of which made the targets of the FRLs ever harder to meet during the worsening recession. Even beyond the network of specific fiscal rules, the deeper institutions and expectations need to motivate respect and enforcement of the rules, otherwise they do little good (Braun and Tommasi 2004).

The FRL or some other measure must assure that the national government acts as a good model for fiscal prudence, both to avoid stressing financial markets and to meet its fiscal commitments to the SNGs. This may be the first aspect tested of the revised FRL in Peru.

The effectiveness of an FRL obviously depends on how well it can be enforced. Countries with weak enforcement mechanisms for an FRL are also likely to have weaknesses in other SN fiscal constraints.

The need for national level discipline and enforcement mechanisms might be arguments for a single comprehensive FRL with top-down rules for all, as in Brazil and Colombia. But getting everyone to agree on the same document, when the national government does not have this constitutional authority (like Mexico, Argentina, India and Canada), could be costly in political capital and fiscal bribes. Going the multi-law route, as in Argentina and India, could work if the national-level law and practice set a proper example and incentives - hard-budget constraints - that motivate the SNGs not only to behave fiscally now, but also to adopt their own institutions to assure future prudence. This was the implicit strategy in the United States, where the no-bailout policy by the federal government since the early 1800 s set up the incentive for many states to constitutionally require budget balance. There, as in Canada and India, the subnational FRLs are endogenous outcomes to the fiscal regime setup from the national level. Either way, whether or not a national FRL sets detailed rules for SNG fiscal policy, the national government (with or without an FRL for itself) has to set hard-budget constraints on the SNGs that enforce ex post the rules for their fiscal prudence. 


\section{References}

Ahmad, Etisham, and Katherine Baer. 1997. "Colombia." In Teresa Ter-Minassian, ed., Fiscal Federalism: Theory and Practice. Washington, D.C.: International Monetary Fund.

Alesina, Alberto. 1994. "Political Models of Macroeconomic Policy and Fiscal Reforms," in S. Haggard and S. B. Webb, ed. Voting for Reform; Democracy, Political Liberalization, and Economic Adjustment. New York: Oxford University Press.

Alfonso, Jose Roberto 2002. "Fiscal Affairs in Brazil," BNDES Presentation. March 2002.

Bird, Richard M. 1984. Intergovernmental Finance in Colombia: Final Report of the Mission on Intergovernmental Finance. Cambridge, Mass.: Harvard Law School International Tax Program.

Bird, Richard M., and Ariel Fiszbein. 1998. "Colombia: the central role of the central government in fiscal decentralization," in R. Bird and F. Vaillancourt, eds., Fiscal Decentralization in Developing Countries. Cambridge, UK: Cambridge University Press.

Bohn, H. and Robert P. Inman. 1996. "Balanced Budget Rules and Public Deficits: Evidence from the U.S. States" Carnegie-Rochester Series on Public Policy. 45: 13-76.

Braun, Miguel and Mariano Tommasi, 2002. "Fiscal Rules for Subnational Governments. Some organizing principles and Latin American experiences." G. Kopits, ed., Rules and Practice in Intergovernmental Fiscal Relations. IMF and World Bank, Washington, DC..

Diaz-Cayeros, Alberto; Beatriz Magaloni; and Barry R. Weingast, 2003. "Tragic Brilliance: Equilibrium Hegemony and Democratization in Mexico," Stanford University, processed.

Dillinger, William, Guillermo Perry and Steven B. Webb. 2003. "Can fiscal stability coexist with decentralization? The case of LAC," in J. Martinez Vazquez, ed., Public Finance in Developing and Transition Countries: Essays in Honor of Richard Bird.

Dillinger, William, and Steven B. Webb. 1999. Fiscal Management in Federal Democracies: Argentina and Brazil. Policy Research Working Paper: 2121. World Bank, Washington, D.C.

Echevarria, J.J., C. Renteria, and R. Steiner. 2000. "Decentralization and bailouts in Colombia" Fedesarrollo Working Paper Series.

Gómez, Eduardo J. and William McCarten. 2001. "Fiscal Responsibility Acts: Why Have They Mushroomed and Will They Enhance Fiscal Discipline?" processed.

Gonzalez, Christian Yves, David Rosenblatt, and Steven B. Webb, 2003 "Stabilizing Intergovernmental Transfers in Latin America: A Complement to National/ Subnational Fiscal Rules?" , in G. Kopits, ed. Rules and Practice in Intergovernmental Fiscal Relations. IMF and World Bank, Washington, DC 2003.

Inman, Robert P. 2003. "Transfers and Bailouts: Lessons from U.S. Federalism," in J. Rodden, G. Eskeland and J. Litvack, ed. Fiscal Decentralization and the Challenge of Hard-Budget Constraints. Cambridge MA and London: MIT Press. 
Jones, Mark P., Pablo Sanguinetti, and Mariano Tommasi. 1999. "Politics, Institutions, and Public Sector Spending in the Argentine Provinces." in James Poterba and Juergen von Hagen, ed., Budget Institutions and Fiscal Outcomes. Chicago: National Bureau of Economic Research and the University of Chicago Press.

Rodden, Jonathan and Gunnar Eskeland 2003. "Conclusions," in J. Rodden, G. Eskeland and J. Litvack, ed. Fiscal Decentralization and the Challenge of Hard-Budget Constraints. Cambridge MA and London: MIT Press.

Rodrik, Dani. 1989. "Promises, Promises: Credible Policy Reform Via Signaling," in The Economic Journal, 99 (September 1989), 756-772.

Stepan, Alfred. 1997. "Toward a Comparative Theory of Federalism.” All Souls' College, Oxford University. Processed.

Teresa Ter-Minassian and Jon Craig 1997. "Control of Subnational Government Borrowing," in TerMinassian ed., Fiscal Federalism: Theory and Practice. Washington, D.C.: International Monetary Fund.

Tommasi, Mariano, 2002. "Fiscal Federalism in Argentina and the Reforms of the 1990's" Mimeo, Center for Research on Economic Development and Policy Reform, Stanford University.

Weingast, Barry, 2003. "The Performance and Stability of Federalism, Mexican Style: An Institutionalist Perspective," Stanford University, processed.

World Bank, 2002. Peru: Public Expenditure Review. Washington, DC. 